\title{
Inoculation with arbuscular mycorrhizal fungi, fertilization and seed rates influence growth and development of lyme grass seedlings in two desert areas in Iceland
}

\author{
Úlfur ÓSKaRSSON ${ }^{1,2}$ and WOLFGang HeYSER ${ }^{2}$ \\ ${ }^{I}$ Agricultural University of Iceland, Reykir, IS-810 Hveragerdi, Iceland.ulfur@lbhi.is (corresponding author) \\ ${ }^{2}$ Universität Bremen, Center for Environmental Research and Sustainable Technology, Leobener Str., D-28359 Bremen, \\ Germany.heyser@uni-bremen.de
}

\begin{abstract}
The potential benefits of artificial inoculation with arbuscular mycorrhizal fungi (AMF) for lyme grass seedling establishment were tested in combination with varying fertilizer and seed rates in a long term revegetation study in two sandy deserts in Iceland. Fertilizer inputs proved more effective than other treatment variables in increasing vegetative growth, flowering and sand accretion of lyme grass seedlings. For this, re-fertilization was more important than the initial dose. AMF inoculation initially improved seedling growth but after the first year the effects became neutral or negative. While fertilization generally reduced AMF colonization, the negative effects of inoculation on lyme grass were enhanced by fertilization. Larger seed doses raised inter- and intraspecific competition, decreasing lyme grass vegetative regeneration and associate vegetation. Based on the current results, the application of AMF inoculation cannot be recommended for lyme grass establishment at the present. However, low seed rates $\left(\leq 50\right.$ seeds $\left.\mathrm{m}^{-2}\right)$ and low initial fertilizer doses $\left(\leq 10 \mathrm{~g} \mathrm{~m}^{-2}\right)$ in combination with moderate re-fertilization application rates for a few years are apparently economical for the establishment of lyme grass for revegetation projects.
\end{abstract}

Keywords: Lyme grass, seedling establishment, AMF inoculation, fertilization, seed rate, flowering, sand accretion.

\section{YFIRLIT}

Svepprótasmitun, áburðar- og frceskammtar hafa áhrif á vöxt og proska melgresis á tveimur sandsvceðum á Íslandi

Möguleg hagnýting innrænna sveppróta til að auðvelda ræktun melgresis var könnuð í langtíma smittilraunum á tveimur sandsvæðum. Mismunandi áburðar- og fræskammtar voru jafnframt prófaðir. Áburður jók vöxt, blómgun og sandsöfnun melgresis meira en aðrar meðferðir, og hafði enduráburðargjöf meiri áhrif en stærð upphafsskammta af áburði. Svepprótasmitun jók í fyrstu vöxt fræplantna en strax á öðru ári urðu áhrifin neikvæð eða hlutlaus. Pótt áburðargjöf drægi almennt úr myndun sveppróta, pá jukust neikvæð áhrif smitunar við aukna áburðargjöf. Samkeppni jókst með auknu sáðmagni, sem dró úr kynlausri fjölgun melgresis og vexti annars gróðurs. Pessar niðurstöður mæla gegn notkun svepprótasmits við að koma melgresisplöntum á legg. Hins vegar virðist hagkvæmt að nota litla fræskammta $\left(\leq 50 \mathrm{fræ} \mathrm{m}^{-2}\right)$ og litla upphafsskammta af áburði $\left(\leq 10 \mathrm{~g} \mathrm{~m}^{-2}\right)$ við ræktun melgresis ásamt hóflegri enduráburðargjöf í nokkur ár eftir sáningu. 


\section{INTRODUCTION}

Sandy deserts and other eroded landscapes cover around 40,000 $\mathrm{km}^{2}$ in Iceland (Arnalds 2010). To protect communities and transportation from drifting sands, and for ecosystem rehabilitation, a few thousand hectares of derelict land are seeded and fertilized annually. One of the main species used for this purpose is the dunebuilding North European perennial lyme grass Leymus arenarius L (Greipsson \& Davy 1994). Lyme grass is efficient in trapping drifting sand within its rigid leaves. It continuously forms new tillers that are its main mode of regeneration within dunes (Greipsson \& Davy 1994). The seed for artificial lyme grass establishment is mechanically collected from wild populations, and after threshing and rinsing, it is coated with silt dust before sowing. To ensure seedling establishment and to accelerate seedling growth, seed drilling is applied and seedlings subsequently fertilized once a year for a few years (Greipsson \& Davy 1997). The growth and sexual reproduction of lyme grass in Icelandic deserts is mostly limited by the nutrients $\mathrm{N}$ and $\mathrm{P}$, but can also be limited by $\mathrm{N}$ alone (Greipsson \& Davy 1997). Seedling tiller density and size is increased by fertilizer application along with seed yields and seed quality (Greipsson \& Davy 1997). High $N$ and $P$ fertilization rates can also shorten the time for lyme grass to reach sexual maturity down to four summers after sowing in the field (Greipsson \& Davy 1997).

Environments with low plant cover, active erosion processes and poor water and nutrient availability are sometimes predominated by non-mycorrhizal plants (Cakan \& Karatas 2006, Cázares et al. 2005, Oehl, et al. 2011). These plants are adapted to take advantage of limited soil resources, using root hairs or specialized root structures for nutrient uptake instead of employing mycorrhizal fungi (Bates and Lynch 2001, Miller 2005). In some cases, however, plants that normally form mycorrhizae may be un-colonized by fungi or may have difficulty in becoming established due to complications associated with the dispersal of two separate individuals that need to cooperate at a fresh site (Yamauchi, et al. 2009, Harris 2009).
As a result, facultative mycotrophic plants have a vital role during primary succession and provide an opportunity for the arrival of mutualistic fungi, which, in turn, make it possible for obligatorily mycotrophic plants to become established (Cázares et al. 2005, Kikvidze et al. 2010).

Mycorrhizae are normally the principal organs for soil-plant interactions and can reduce the cost of plants for water and nutrient acquisition (Smith \& Read 2008). Arbuscular mycorrhiza (AM) is globally the most common type of mycorrhizae, estimated to be associated with $74 \%$ of all plant species (van der Heijden et al. 2015). AM is often present at the early start of primary succession, being infrequent and perhaps inconsequential at first but later having a dominating influence on plant development (Kikvidze et al. 2010). Like other types of mycorrhizae, AM fungi (AMF) can reach a larger volume of soil than un-colonized roots and provide a better access to slowly soluble forms of soil nutrients, particularly P (Smith \& Read 2008), but also organic soil N (Hodge \& Storer 2015). AMF, like many other mutualistic rhizosphere organisms, furthermore reduce biotic stress of plants, improving protection against pathogens, pests and parasitic plants (Jung et al. 2012). Extramatrical mycelium networks created by mycorrhizal fungi may constitute a significant part of the soil microbial biomass and functioning (Leake et al. 2004). By linking plants together, these networks can facilitate the allocation of mineral nutrients and carbon, and influence the development of vegetation communities (Bever et al. 2010, Kernaghan 2005, Simard \& Durall 2004, van der Heijden \& Horton 2009).

AMF inoculation is generally considered to be effective in facilitating artificial plant establishment in degraded environments (Harris 2009). Although AMF are an important component of the soil biota for ecosystem rehabilitation, responses of pioneer plants to artificial inoculation are very variable and depend on plant and fungal species and are subject to the physical, biological and chemical plant environment (Johnsson et al. 1997, Corkidi 
\& Rincón 1997, Busby et al. 2011, HerreraPeraza et al. 2011, Hoeksema et al. 2010). The application of fungal species and strains that fit individual plant species and are adapted to particular environments generally gives better results than commercial inocula (Maltz \& Trester 2015, Klironomos 2003, Requena et al. 2001, Pellegrino et al. 2011).

Unvegetated sandy deserts in Iceland contain very few propagules of arbuscular mycorrhizal fungi AMF, but desert vegetation patches may often contain AMF spores and mycorrhizae (Greipsson \& El-Mayas 2000). Lyme grass is usually found at a young age without mycorrhiza but forms arbuscular mycorrhiza some years after seedling establishment (Greipsson \& ElMayas 2000, Greipsson et al. 2002). As lyme grass grows older, AMF propagule density increases and considerable species richness of AMF communities develops (Greipsson et al. 2002). Greipsson \& El-Mayas (2000) found no AMF in 5 year old seeded lyme grass, but four and six AMF species were found in 10 year old seeded lyme grass and an older natural dune, respectively. Glomus hoi was the most frequent AMF species found in lyme grass dunes but also found were G. clarum and unidentified AMF taxa that belonged to the genera Acaulospora, Entrophospora, Glomus and Scutellospora (Greipsson et al. 2002).

Research on the application of AMF inoculum has mainly involved the establishment of lyme grass (Leymus arenarius) for ecosystem rehabilitation activities. These experiments have shown that young lyme grass seedlings can respond responsively to AMF inoculation. Enkhtuya et al. (2003) showed that survival and growth of first year lyme grass seedlings in Icelandic deserts was enhanced by AMF inoculation and Greipsson and El-Mayas (2000) found a similar mycorrhizal benefit in a pot study. These encouraging results led to the establishment of a large field experiment to help realize the potential benefits of AMF inoculation in lyme grass field establishment and to investigate if other inputs and costs could be reduced. For artificial lyme grass establishment, seed collection and handling are the main costs
(Greipsson \& Davy 1997), but fertilization applications are also expensive.

The primary objective of the present study was to investigate if AMF inoculation can hasten the establishment, growth and reproduction of lyme grass seedlings and thereby reduce the need of fertilizer and seed inputs in revegetation projects.

\section{MATERIAL AND METHODS}

Field experiments involving lyme grass seedling establishment were laid out at two sandy desert areas in Southern Iceland, a costal and an inland site (Figure 1). Four main treatment variables were tested in the experiment: AMF inoculation, initial fertilizer doses, seed rates and re-fertilization (Table 1).

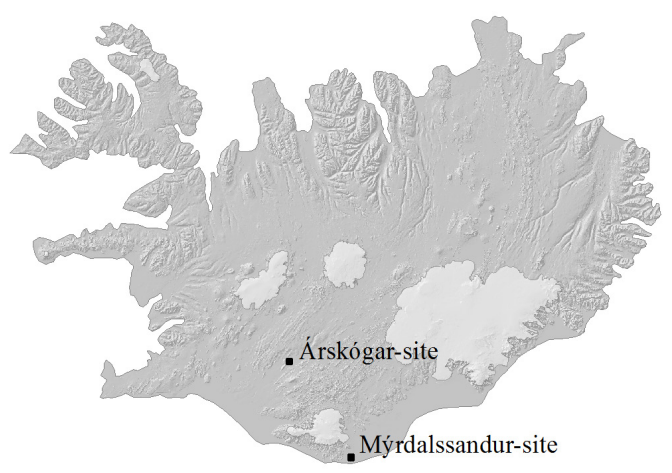

Figure 1. The locations of the two study sites within Iceland; the inland site Árskógar and the coastal site Mýrdalssandur.

\section{Lyme grass seed}

Seeds of lyme grass from a local source were provided by the Soil Conservation Service, Gunnarsholt, Iceland, coated with silt dust to increase the specific density and to even out the seed surface to facilitate passage through a drill machine. At the coastal site (Figure 1) two seed rates were tested, 3.8 and $7.6 \mathrm{~g} \mathrm{~m}^{-2}$; the latter is a normal rate of coated seeds. The seed stock had around a $75 \%$ germination rate which meant that the seed doses contained around 50 and 100 viable seeds $\mathrm{m}^{-2}$ (Table 1). At the inland site the seed rate was fixed at the higher seed rate, 7.6 
Table 1. Range of study treatments (independent variables) at the two sites.

\begin{tabular}{lcccc}
\hline Study sites & $\begin{array}{c}\text { Initial fertilizer } \\
\text { doses }\end{array}$ & $\begin{array}{c}\text { Inoculum } \\
\text { doses }\end{array}$ & $\begin{array}{c}\text { Seed } \\
\text { rates }\end{array}$ & $\begin{array}{c}\text { Re-fertilization in the } \\
\mathbf{2}^{\text {nd }} \text { and } \mathbf{3}^{\text {rd }} \text { summers }\end{array}$ \\
\hline Inland site & 3 treatments & 4 treatments & 1 treatment & 2 treatments \\
& $0,10 \& 20 \mathrm{~g} \mathrm{~m}^{-2}$ & $0,12,24 \& 36 \mathrm{~g} \mathrm{~m}^{-2}$ & 100 viable seeds m & $0 \& 20 \mathrm{~g} \mathrm{~m}^{-2} \mathrm{y}^{-1}$ \\
Coastal site & 2 treatments & 3 treatments & 2 treatments & 2 treatments \\
& $10 \& 20 \mathrm{~g} \mathrm{~m}^{-2}$ & $0,12 \& 24 \mathrm{~g} \mathrm{~m}^{-2}$ & 50 and 100 viable seeds $\mathrm{m}^{-2}$ & $0 \& 20 \mathrm{~g} \mathrm{~m}^{-2} \mathrm{y}^{-1}$ \\
\hline
\end{tabular}

$\mathrm{g} \mathrm{m}^{-2}$, or around 100 viable seeds $\mathrm{m}^{-2}$ (Table 1 ).

\section{Inoculum}

The inoculum tested was a commercial AMF inoculum, TerraVital-D (Plantworks Ltd. Sittingbourne, UK) and contained five AMF isolates: Rhizophagus iregularis (syn. Glomus intraradices) BEG98, G. mosseae BEG25, G. hoi IS1, G. geosporum BEG11 and G. claroideum IS4. The G. hoi and G. claroideum isolates were obtained from spores in lyme grass dunes in Iceland (Greipsson et al. 2002). The TerraVital-D product contained an optimized mixture $(5 \%$ of weight) of slow-release fertilizers: natural humates, seaweed extract and serpentinite. At both sites the inoculum was tested at different application levels (Table 1); at the coastal site the levels were two, 12 and $24 \mathrm{~g} \mathrm{~m}^{-2}$ (the latter was the dose of inoculum recommended by the inoculum producer) along with an un-inoculated control. The same levels and an un-inoculated control were also used at the inland site along with the third inoculum dose of $36 \mathrm{~g} \mathrm{~m}^{-2}$. The inoculum was added once during the sowing of the experiment (see Experimental design and establishment procedure).

\section{Initial fertilization}

For the initial fertilizer treatment during sowing a granulated NP fertilizer, Fjölmóði 2 (Áburðarverksmiðjan, Reykjavík, Iceland), was applied, which contained $23 \% \mathrm{~N}$ and $5.2 \% \mathrm{P}$. At the coastal site two levels of this fertilizer were tested, 10 and $20 \mathrm{~g} \mathrm{~m}^{-2}$, the latter being the normal dose used for lyme grass sowings (Table 1). The lower dose equaled $2.3 \mathrm{~g} \mathrm{~N} \mathrm{~m}^{-2}$ and $0.5 \mathrm{~g}$ $\mathrm{P} \mathrm{m}^{-2}$ and the higher dose $4.6 \mathrm{~g} \mathrm{~N} \mathrm{~m}^{-2}$ and $1.0 \mathrm{~g} \mathrm{P}^{-1}$ $\mathrm{m}^{-2}$. At the inland site, the same fertilizer levels were applied plus an unfertilized control (Table $1)$.

\section{Experimental design and establishment procedure}

A full factorial experiment was laid out at both sites. The size of treatment units (plots) was around $5 \times 30 \mathrm{~m}$ or $150 \mathrm{~m}^{2}$. The minimum distance between plots was $5 \mathrm{~m}$. The 12 plots at both sites were randomly distributed within each of five blocks. In total, 60 plots were seeded at each site. After dividing each plot in two in the $2^{\text {nd }}$ summer for re-fertilization purposes, the total number of subplots was 120 at each site. The experiment at the coastal site was seeded on 16 May and at the inland site on 16 June 2003.

For seeding the experiments, a tractor driven drill-machine, modified for difficult terrain for large-scale revegetation purposes, was provided by the Soil Conservation Service, Iceland. The drill machine had two containers, one for the lyme grass seeds and one for the fertilizer. Prior to sowing of each appropriate treatment, the AMF inoculum dose was mixed with the granulated fertilizer dose and the drill machine seed and inoculum-fertilizer outputs adjusted to scheduled rates. The lyme grass seeds were drill-seeded to a depth of approximately $5 \mathrm{~cm}$ and the fertilizer or the inoculum-fertilizer mixture placed around 1-2 $\mathrm{cm}$ below the seed furrow.

\section{Re-fertilization}

To examine the effects of repeated fertilization, the $150 \mathrm{~m}^{2}$ plots were split across in two subplots equal in size and either one chosen 
randomly for re-fertilization and the other subplots left unfertilized. The re-fertilization was done in June in the $2^{\text {nd }}$ and $3^{\text {rd }}$ summers after sowing and the dose was $20 \mathrm{~g} \mathrm{~m}^{-2} \mathrm{y}^{-1}$ (Table 1). In the $2^{\text {nd }}$ summer the NP fertilizer Fjölmóði $2(23 \% \mathrm{~N}, 5.2 \% \mathrm{P})$ was applied, but in the $3^{\text {rd }}$ year a NPK fertilizer Fjölgræðir 7 was used (Áburðarverksmiðjan, Reykjavík, Iceland), containing $22 \% \mathrm{~N}, 6.1 \% \mathrm{P}, 7.5 \% \mathrm{~K}, 1.6 \% \mathrm{Ca}$ and $2 \% \mathrm{~S}$. In the $2^{\text {nd }}$ summer this equaled $4.6 \mathrm{~g}$ $\mathrm{N} \mathrm{m}^{-2}$ and $1.0 \mathrm{~kg} \mathrm{P} \mathrm{m}^{-2}$ and in the $3^{\text {rd }}$ summer 4.4 $\mathrm{g} \mathrm{N} \mathrm{m}^{-2}$ and $1.2 \mathrm{~g} \mathrm{P} \mathrm{m}^{-2}$.

\section{Sites}

The coastal study site was situated in the middle of the glacio-fluvial area Mýrdalssandur which covers $700 \mathrm{~km}^{2}$ of the south coast of Iceland (Figure 1). It has been formed by reoccurring flood events in past centuries, the largest having a peak flow rate of $300,000 \mathrm{~m}^{3} \mathrm{~s}^{-1}$ (Thordarson \& Larsen 2007), during volcanic eruptions under the Mýrdalsjökull glacier. In addition, glacial rivers and smaller floods continuously deposit silt and sand in the area, which provides a constant source of drifting sand.

The inland study site lies in the eroded volcanic area of Árskógar, covering around 100 $\mathrm{km}^{2}$ near Mt Hekla volcano (Figure 1). The area was previously covered with birch woodland and fertile Andosols, but following the loss of woodland cover due to human activities in past centuries, large scale erosion converted the area largely into a desert. Exposed lava outcrops often overlain with fresh pumice and ash from resent volcanic eruptions in Mt Hekla (Thordarson \& Larsen 2007) cover the landscape and are a source of drifting sand.

The sites chosen for the experiments were flat unsheltered sand-terrain, fluvial in origin, with less than $1 \%$ plant cover. In Iceland, sandy areas are generally glacio-fluvial and volcanic in origin and mostly consist of black basaltic volcanic glass (Arnalds et al. 2001). Unvegetated sands contain very low amounts of $\mathrm{N}\left(<0.1 \mathrm{~g} \mathrm{~kg}^{-1}\right)$ due to lack of organic matter and are low in available $\mathrm{P}$, enhanced by high P-retention of soil colloids (Arnalds \& Kimble 2001).

The coastal study area has a coastal climate type Cfc (Peel et al. 2007), where the annual mean temperature is around $5^{\circ} \mathrm{C}$, and January and July around $1{ }^{\circ} \mathrm{C}$ and $12^{\circ} \mathrm{C}$, respectively (estimated from the nearest weather stations; Icelandic Meteorological Office 2015). Precipitation is evenly distributed throughout the year, around $2000 \mathrm{~mm} \mathrm{y}^{-1}$ (Icelandic Meteorological Office 2015). In contrast, the inland study area falls in between two climate groups; a coastal climate type Dfc and tundra climate ET (Peel et al. 2007), where the annual mean temperature is around $2^{\circ} \mathrm{C}$, and January and July around $-3^{\circ} \mathrm{C}$ and $10^{\circ} \mathrm{C}$, respectively (estimated from the nearest weather stations; Icelandic Meteorological Office 2015). Precipitation is evenly distributed throughout the year, around $1000 \mathrm{~mm} \mathrm{y}^{-1}$ (Icelandic Meteorological Office 2015).

Some sections of both study areas have been subject to intensive revegetation activities in past decades, including large scale areal and ground sowing and fertilization (Aradottir 2007; Gunnarsson \& Indridadottir 2009).

\section{Harvest and evaluation}

Lyme grass plant density (number of plants per area) and plant above-ground yield (dry weight per area) were evaluated in AugustSeptember for the first three summers after sowing, in 2003-2005, at the coastal site, but for the first two summers at the inland site. For this, three $0.25 \mathrm{~m}^{2}$ squares were selected randomly within each $75 \mathrm{~m}^{2}$ subplot and all plants counted and harvested. Above-ground yield of associate vegetation within the squares was also simultaneously harvested. New lyme grass tillers were counted annually for the first two summers at both sites to evaluate the rate of vegetative regeneration, but otherwise included in the total number of plants. Average individual plant size was derived from plant density and above-ground yield. Above-ground parts of lyme grass and associate vegetation were dried at $70^{\circ} \mathrm{C}$ to a constant weight and weighed to the nearest milligram. The occurrences and density of flower spikes were monitored throughout the study period. In the $11^{\text {th }}$ summer after establishment (2013), lyme grass plant height 
and density, cover of lyme grass plants and associate vegetation, and the height of sand accretion were measured.

In the $2^{\text {nd }}$ summer after sowing, root samples were taken at random from three excavated seedlings in each subplot from around $20 \%$ of all subplots at the coastal site to estimate root fungal colonization. In the $3^{\text {rd }}$ summer, root samples were also collected from three randomly chosen plants at all subplots in two blocks at the inland site and from all subplots in all five blocks at the coastal site. Root samples within a subplot were combined to make one sample. Sampling was done in August-September. The root samples were preserved in $70 \%$ ethanol. Before examination, the roots were carefully rinsed with tap water, and cleared in $10 \% \mathrm{KOH}$ and then stained with 1\% Parker Quink Ink in lactoglycerol (Vierheilig et al. 1998). Root subsamples (total root length $>25 \mathrm{~cm}$ ) taken at random from the original samples, were mounted on glass slides and examined under a compound microscope at x 200 magnification. Quantification of AMF colonization, AMF arbuscules and vesicles was done on randomly selected slide positions according to McGonigle (1990) with a minimum of 100 root intersections. The AMF parameters are expressed per root length. The occurrence of other fungi was also registered in the same manner.

\section{Statistical analysis}

To study effects of independent variables on response parameters for both experiments, a factorial ANOVA was applied. Up to three-way interactions were included in the model for plant and fungal parameters plus the main effects of blocks in the experiments. The following model was used:

$\mathrm{Y}_{\mathrm{ijklr}}=\mu+\mathrm{a}_{\mathrm{i}}+\mathrm{b}_{\mathrm{j}}+\mathrm{c}_{\mathrm{k}}+\mathrm{d}_{1}+\mathrm{e}_{\mathrm{r}}+(\mathrm{ab})_{\mathrm{ij}}+(\mathrm{ac})_{\mathrm{ik}}+$ $(\mathrm{ad})_{\mathrm{il}}+(\mathrm{bc})_{\mathrm{jk}}+(\mathrm{bd})_{\mathrm{jl}}+(\mathrm{cd})_{\mathrm{kl}}+(\mathrm{abc})_{\mathrm{ijk}}+(\mathrm{abd})_{\mathrm{ijl}}+$ $(\mathrm{acd})_{\mathrm{ikl}}+(\mathrm{bcd})_{\mathrm{jkl}}+\varepsilon_{\mathrm{ijklr}}$,

where:

$\mathrm{Y}_{\mathrm{ijklr}}$ is response variable jiklr

$\mu$ is variable mean

$a_{i}$ is fertilizer effect at $i$ levels $b_{j}$ is AMF inoculum effect at $i$ levels

$c_{k}$ is seed effect at $i$ levels

$\mathrm{d}_{1}$ is re-fertilization effect at 1 levels

$\mathrm{e}_{\mathrm{r}}$ is block effect (random effect at five levels, $r$ )

$(\mathrm{ab})_{\mathrm{ij}}+(\mathrm{ac})_{\mathrm{ik}}+(\mathrm{ad})_{\mathrm{il}}+(\mathrm{bc})_{\mathrm{jk}}+(\mathrm{bd})_{\mathrm{jl}}+(\mathrm{cd})_{\mathrm{kl}}$ are

second order treatment interactions

$(\mathrm{abc})_{\mathrm{ijk}}+(\mathrm{abd})_{\mathrm{ijl}}+(\mathrm{acd})_{\mathrm{ikl}}+(\mathrm{bcd})_{\mathrm{jkl}}$ are third order

treatment interactions and

$\varepsilon_{\mathrm{ijklr}}$ error term of variable response.

The model for the inland site did not contain the effect c, as seed rates were fixed at this site. Tukey's HSD test and Least Squares Means were used to find significant main and interaction effects, respectively.

Principal component analysis was used to calculate eigenvalues of treatment effects and response variables. Also included for the inland site in the $3^{\text {rd }}$ summer was the AMF colonization. The results were used to estimate the temporal changes and relative organization in eigenvalues throughout the course of the experiment.

Statistical analyses were done by SAS 9.2 for Windows (SAS Institute Inc. 2002-2008).

\section{RESULTS}

Early effects of initial treatments

Inland site. In the $1^{\text {st }}$ summer at the inland site, all response variables were significantly explained by the model for treatment variables at the time of sowing but in the $2^{\text {nd }}$ summer only variation in lyme grass plant density and associate vegetation yield were significantly explained (Table 2). In the $1^{\text {st }}$ summer, most lyme grass parameters were positively influenced by the main effects of fertilization and inoculation, but in the $2^{\text {nd }}$ summer, only fertilization had significant effects. Due to the presence of control plots without fertilizer at this site, fertilization effects were particularly apparent for lyme grass yield, plant size and vegetative regeneration (Table 2 ). In the $1^{\text {st }}$ summer, the difference between unfertilized plants and those receiving the lower fertilizer dose was around fivefold for plant size and yield (Figure 2a). No vegetative regeneration occurred in the $1^{\text {st }}$ summer without fertilizer. In the $2^{\text {nd }}$ summer, the difference in yield (Figure 


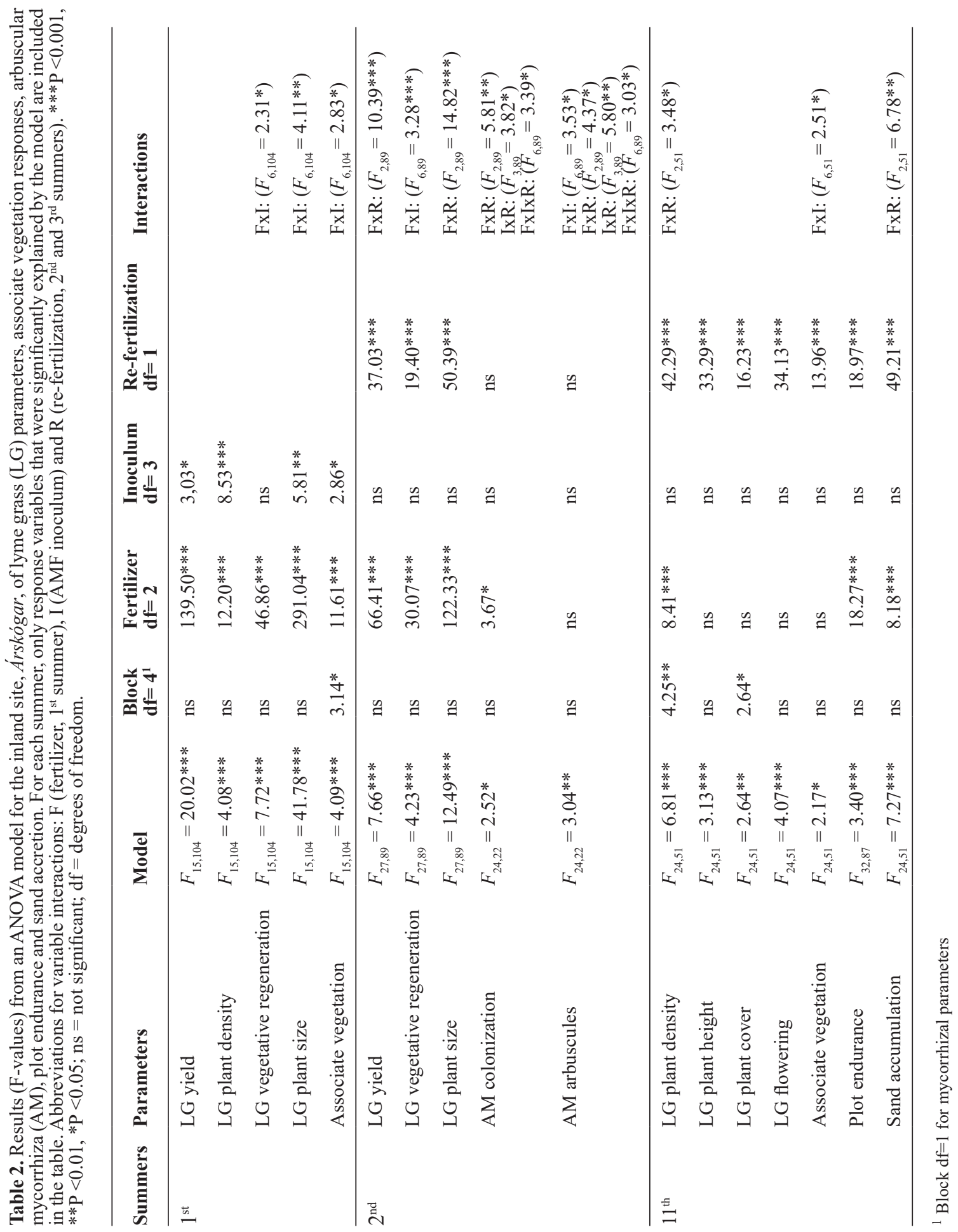



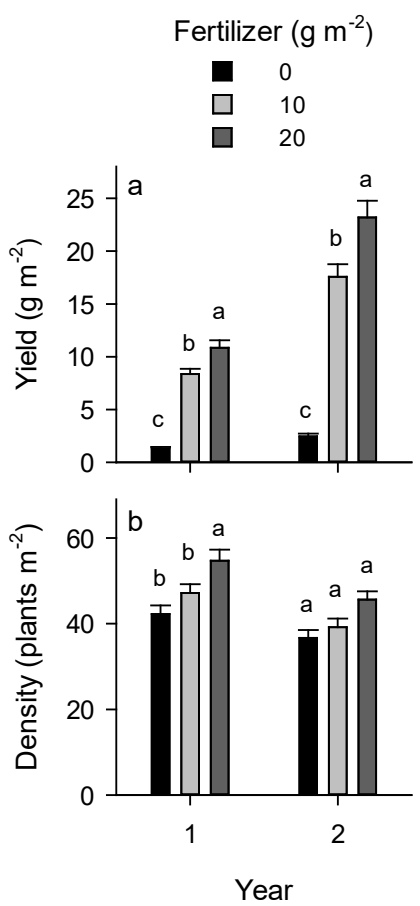

Figure 2. Variations in lyme grass yield (a) and plant density (b) by fertilizer doses, in the $1^{\text {st }}$ and $2^{\text {nd }}$ summers at the inland site Árskógar. The columns represent treatment means and their SE. Different column letters illustrate significant differences within years $(\mathrm{P}<0.05)$.

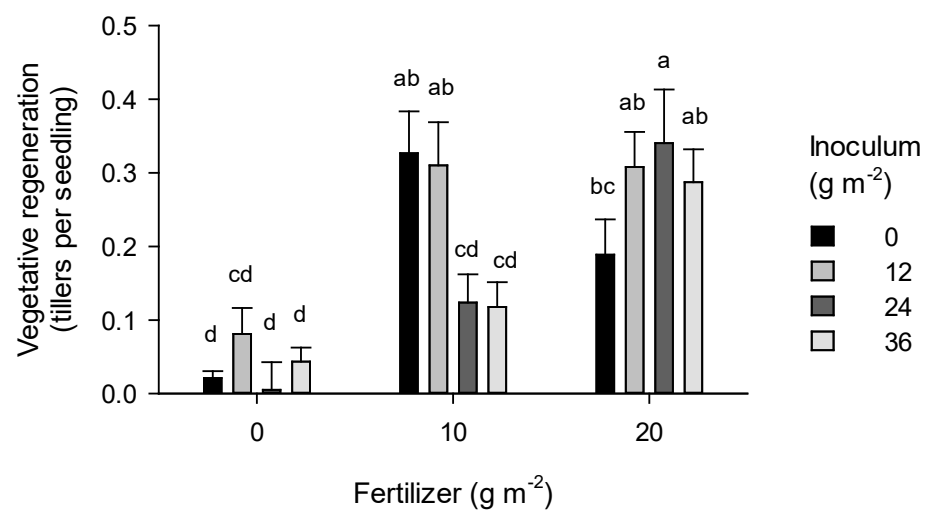

Figure 3. Variation in lyme grass vegetative regeneration in the $2^{\text {nd }}$ summer by fertilizer and inoculum doses at the inland site Árskógar. The columns represent treatment means and their SE. Different column letters show significant differences $(\mathrm{P}<0.05)$. 2a), plant size and vegetation regeneration was around 6-7 fold between unfertilized plants and those receiving the lower fertilizer dose. The responses of plant density were less pronounced (Table 2). The high fertilizer dose produced $29 \%$ higher density in the $1^{\text {st }}$ summer than for unfertilized plants (Figure 2b).

Plants receiving the highest inoculum dose in the $1^{\text {st }}$ summer had a $32 \%$ higher yield than un-inoculated plants (not shown). In the $1^{\text {st }}$ summer, the interaction between inoculation and fertilization (Table 2) showed that high levels of both types of input stimulated vegetative regeneration, reaching 0.09 tillers per seedling. In the $2^{\text {nd }}$ summer inoculation amplified vegetative regeneration to around 0.34 tillers per seedling at the $20 \mathrm{~g} \mathrm{~m}^{-2}$ fertilizer level, while plants receiving $10 \mathrm{~g} \mathrm{~m}^{-2}$ fertilizer were negatively affected by the largest inoculum doses (Figure 3). Similarly, plant size in the $1^{\text {st }}$ summer was only affected by inoculum doses at the $10 \mathrm{~g} \mathrm{~m}^{-2}$ fertilizer level, where the lowest inoculum dose, $12.5 \mathrm{~g} \mathrm{~m}^{-2}$, produced larger plants than other inoculum treatments (not shown). Furthermore, the two largest inoculum doses produced $24 \%$ and $32 \%$ higher plant densities in the $1^{\text {st }}$ and $2^{\text {nd }}$ summers, respectively, than that of un-inoculated plants.

Associated vegetation also responded positively to fertilization in the $1^{\text {st }}$ summer (Table 2), reaching $0.21 \mathrm{~g} \mathrm{~m}^{-2}$ with ample fertilizer (not shown). Associate vegetation also grew better with the highest inoculum dose than with the second highest dose. The highest fertilizer dose and the highest inoculum dose combined encouraged growth of associate vegetation, to a maximum of $0.40 \mathrm{~g} \mathrm{~m}^{-2}$, while inoculum had less effect at a lower fertilizer dose. The most common plant species at the inland site were: Agrostis 


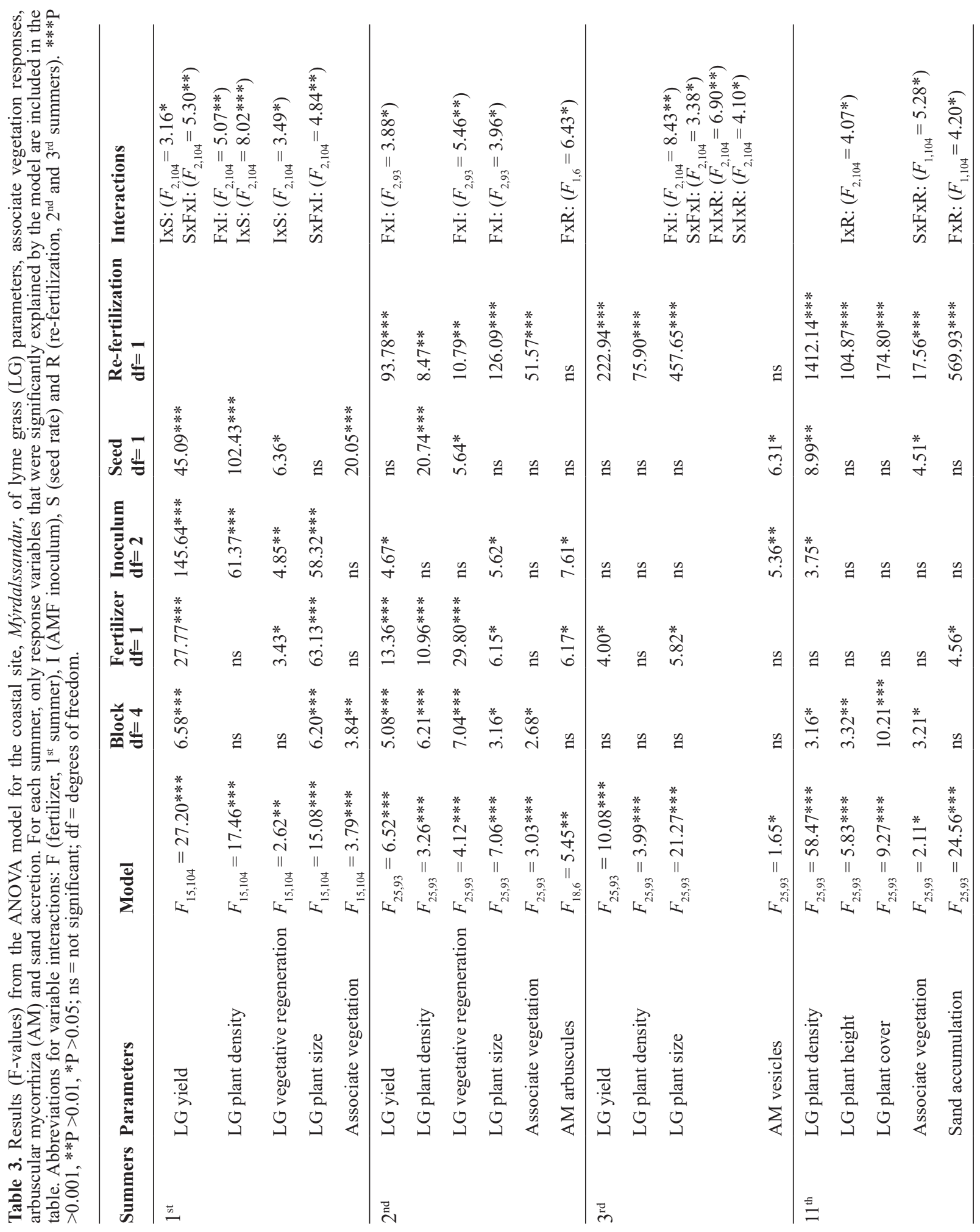



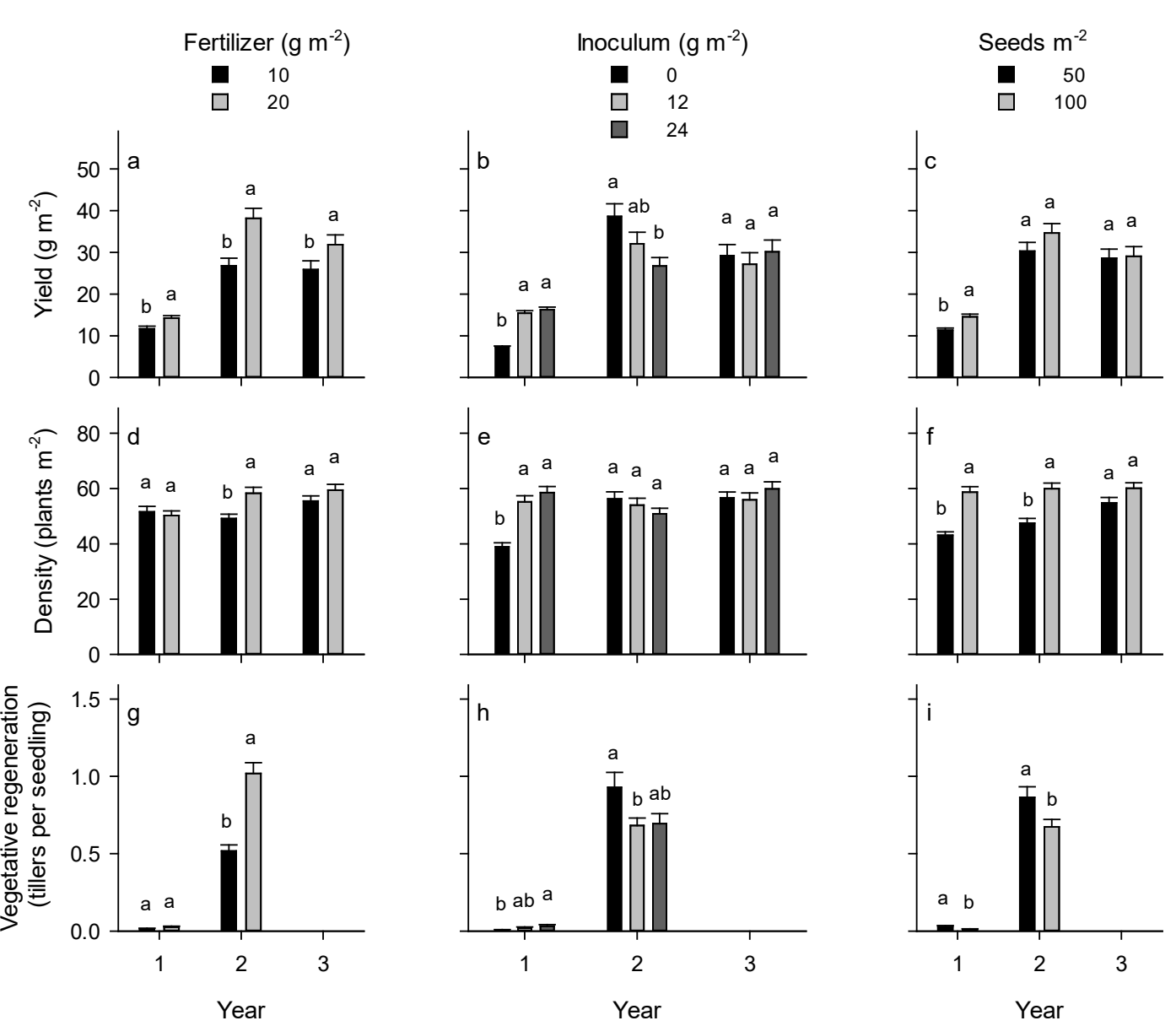

Figure 4. Variation in lyme grass yield $(a-c)$, lyme grass plant density $(d-f$,$) and degree of vegetative regen-$ eration ( $\mathrm{g}-\mathrm{i}$ ) by fertilizer doses, inoculum doses and seed rates in the $1^{\text {st }}-3^{\text {rd }}$ summers at the coastal site Mýrdalssandur. The columns represent treatment means and their SE. Different column letters illustrate significant differences within years $(\mathrm{P}<0.05)$.

stolonifera L., Festuca richardsonii Hooker, Rumex acetosella L. and Silene uniflora A. Roth. Other plant species found at the site were: Calamagrostis stricta (Timm.) Koeler, Cardaminopsis petraea (L.) Hiit., Deschampsia beringensis Hult and Rumex acetosa L.

Coastal site. At the coastal site, treatment variables at the time of sowing were influential of most lyme grass parameters for the first two summers (Table 3 ). The influences of inoculum and seed doses were greatest in the $1^{\text {st }}$ summer but the initial fertilizer was effective for the first two summers (Table 3).
In the $1^{\text {st }}, 2^{\text {nd }}$ and $3^{\text {rd }}$ summers, doubling of the initial fertilizer dose increased yield by around $22 \%, 43 \%$ and 23\%, respectively (Figure $4 a$ ). The larger inoculum dose more than doubled yield in the $1^{\text {st }}$ summer, compared to that of un-inoculated plants, but in the $2^{\text {nd }}$ summer the effects of inoculation became strongly negative and then neutral in the $3^{\text {rd }}$ summer (Figure $4 \mathrm{~b}$ ). Doubling of seed rate increased yield by around $28 \%$ in the $1^{\text {st }}$ summer (Figure $4 \mathrm{c}$ ). At the higher seed rate, the positive effects of inoculation on yield were escalated in the $1^{\text {st }}$ summer, as indicated by the significant interaction between 
these variables (Table 3). Furthermore, the threeway interaction between fertilizer, inoculum and seed rate (Table 3 ) showed that the highest doses of all variables resulted in the highest yield, $20.3 \mathrm{~g} \mathrm{~m}^{-2}$ (not shown). In the $2^{\text {nd }}$ summer, the interaction between fertilization and inoculation (Table 3) showed that the increase in yield due to a larger fertilizer dose was only realized with un-inoculated plants, where yield reached 48.5 $\mathrm{g} \mathrm{m}^{-2}$ (Figure $5 \mathrm{a}$ ).

Doubling of fertilizer influenced plant density in the $2^{\text {nd }}$ summer, increasing it by $19 \%$ (Figure 4d). Inoculation, however, affected plant density in the $1^{\text {st }}$ summer, increasing plant density by around 50\% regardless of inoculum dose (Figure 4e). Doubling the seed rate increased it by $36 \%$ and $26 \%$ in the $1^{\text {st }}$ and $2^{\text {nd }}$ summers, respectively (Figure $4 \mathrm{f}$ ). In the $1^{\text {st }}$ summer, variable interactions (Table 3 ) showed that the positive response in plant density to

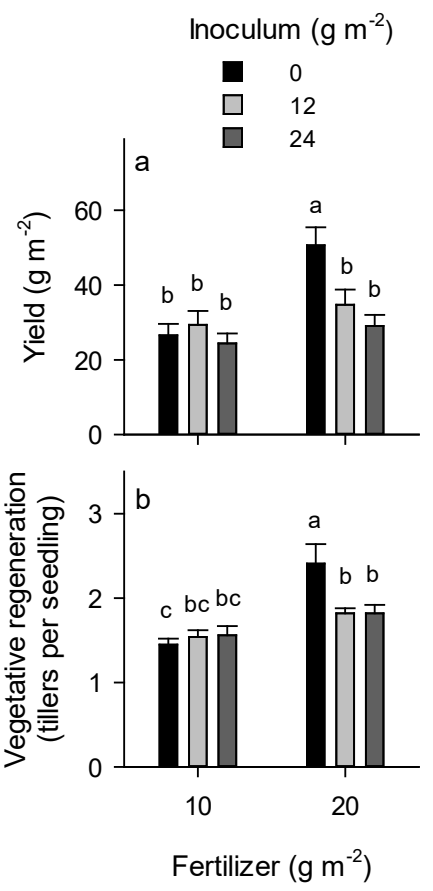

Figure 5. Variation in lyme grass yield (a) and vegetative regeneration (b) in the $2^{\text {nd }}$ summer by fertilizer and inoculum doses at Mýrdalssandur. The columns represent treatment means and their SE. Different column letters show significant differences $(\mathrm{P}<0.05)$. inoculation was enhanced at the higher fertilizer and seed rate, reaching 59.9 and 67.5 plants $\mathrm{m}^{-2}$, respectively (not shown).

In the $1^{\text {st }}$ summer, inoculation increased plant size by around 50\%, regardless of inoculum dose, and doubling of fertilizer increased plant size by $31 \%$ (not shown). At the same time, average plant size was greatest 0.37 $\mathrm{g}$ in treatments receiving the larger fertilizer and larger seed dose at the lower inoculum level, as indicated by the three-way interaction between these variables (Table 3 ). In the $2^{\text {nd }}$ summer, plants receiving the larger inoculum dose were $24 \%$ smaller than un-inoculated plants, while plants receiving the larger initial fertilizer dose were 19\% larger (not shown). The increase in plant size due to the larger fertilizer dose was, however, only apparent in un-inoculated plants, as indicated by the interaction between fertilizer and inoculum in the $2^{\text {nd }}$ and $3^{\text {rd }}$ summers (not shown). In the $3^{\text {rd }}$ summer, initial fertilization still had a positive effect on plant size (not shown). At the same time, the three way interaction between fertilizer, inoculum and seed rate (Table 3) revealed that the positive effect on plant size of a larger fertilizer dose was only significant with un-inoculated plants and the larger seed dose (not shown).

Lyme grass vegetative regeneration was low in the $1^{\text {st }}$ summer, but was stimulated by inoculation and reduced by a higher seed rate (Figures $4 \mathrm{~g}, \mathrm{~h} \& \mathrm{i}$ ). The interaction between inoculum and seed rate in the $1^{\text {st }}$ summer (Table 3 ) produced the highest rate of 0.05 tillers per seedling with high inoculum and low seed dose (not shown). In the $2^{\text {nd }}$ summer, inoculation and high seed rate generally reduced vegetative regeneration (Figures $4 \mathrm{~h} \& \mathrm{i}$ ). At the same time, vegetative regeneration was significantly increased by a larger fertilizer dose (Figure $4 \mathrm{~g}$ ). The interaction between fertilization and inoculation (Table 3 ) revealed that this response was only realized among un-inoculated plants, where the regeneration rose to 2.4 tillers per seedling with ample fertilizer (Figure 5b).

At the coastal site the most common plant species were: $A$. stolonifera, C. petraea, Honckenya peploides (L.) Ehrh., R. acetosella 
and S. uniflora. Other plant species found at the site were: Carex maritima Gunn., Plantago maritima $\mathrm{L}$. and $R$. acetosa. In the $1^{\text {st }}$ summer, the associate vegetation was reduced by increasing seed rate, from 2.0 to $0.01 \mathrm{~g} \mathrm{~m}^{-2}$ (not shown).

\section{Early effects of re-fertilization}

In the $2^{\text {nd }}$ summer, repeated fertilization became the main factor controlling lyme grass parameters and the growth of associate vegetation (Table 2 $\& 3)$. The response was greater at the coastal site than at the inland site (Table $2 \& 3$, Figures 6a-f).

$$
\begin{gathered}
\text { Re-fertilization }\left(\mathrm{g} \mathrm{m}^{-2} \mathrm{y}^{-1}\right) \\
\longrightarrow \multimap 20 \\
-000
\end{gathered}
$$
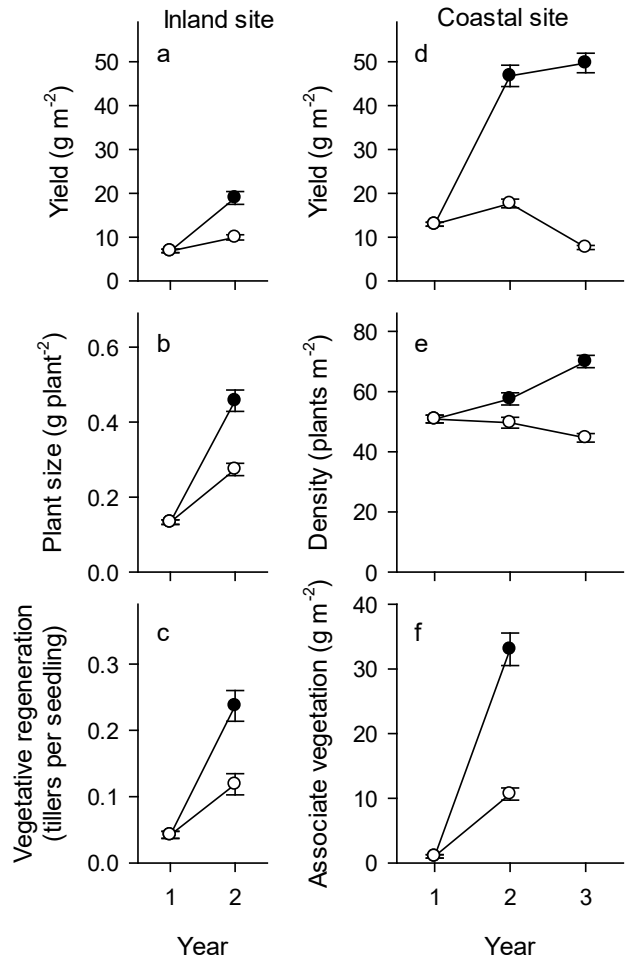

Figure 6. Changes in lyme grass yield (a \& d), plant unit weight (b), lyme grass tiller production (c), plant density (e), and natural vegetation cover (f) with time and re-fertilization. Figs. a-c are from the inland site Árskógar, and figs d-f are from the coastal site Mýrdalssandur. The dots represent treatment means and their SE.
At the inland site lyme grass yield, plant size and vegetative regeneration rose by $90 \%, 66 \%$ and $100 \%$, respectively, due to re-fertilization (Figures 6a-c). The interaction between initial fertilization and re-fertilization (Table 2) was synergistic as greater lyme grass yield was attained with a large initial fertilizer dose and re-fertilization, reaching $32.6 \mathrm{~g} \mathrm{~m}^{-2}$ in the $2^{\text {nd }}$ summer (not shown).

At the coastal site in the $2^{\text {nd }}$ summer, lyme grass yield rose by $164 \%$ due to refertilization (Figure 6d). At the same time, plant density (Figure 6e), plant size and vegetative regeneration rose by $16 \%, 128 \%$ and $50 \%$, respectively, and associate vegetation more than doubled (Figure 6f). In the $3^{\text {rd }}$ summer, yield (Figure 6d), plant density (Figure 6e) and plant size shrank from the previous summer in plots without re-fertilization. Therefore, in the $3^{\text {rd }}$ summer, the difference between plants with and without re-fertilization grew to $550 \%, 57 \%$ and 319\% for yield (Figure 6d), plant density (Figure 6e) and plants size, respectively. In the $3^{\text {rd }}$ summer, the three-way interaction of initial fertilizer, inoculum and re-fertilization (Table 3) showed that plant size in re-fertilized plots at the lower initial fertilizer level was greater with $12 \mathrm{~g} \mathrm{~m}^{-2}$ inoculum dose than other inoculum treatments. However, the $12 \mathrm{~g} \mathrm{~m}^{-2}$ inoculum dose produced smaller plants than other inoculum treatments at the higher initial fertilizer level (not shown). Another three-way interaction between inoculum, seed rate and refertilization (Table 3 ) revealed that the negative effect of higher seed rate on plant size was only evident in re-fertilized plots that received the highest inoculum dose (not shown).

\section{Mycorrhizal colonization}

In the $2^{\text {nd }}$ summer at the inland site, AMF colonization of lyme grass averaged $7.1 \%$ of root length and was negatively affected by the high initial fertilizer level, which lowered the colonization rate by more than a half compared to other treatments (Figure 7a). At the same time, interactions involving initial fertilizer, inoculum and re-fertilization (Table 2) showed that re-fertilization had positive effects on AMF 


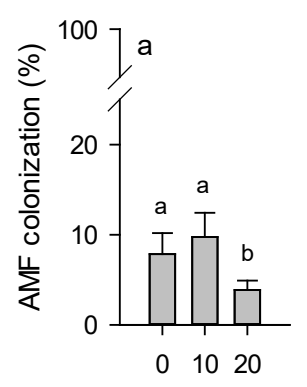

Fertilizer $\left(\mathrm{g} \mathrm{m}^{-2}\right)$

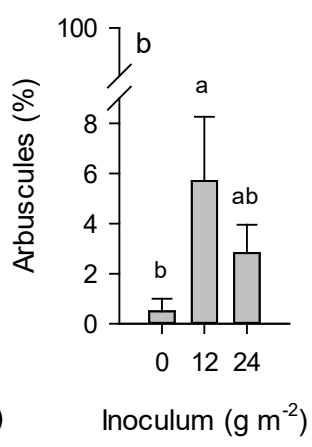

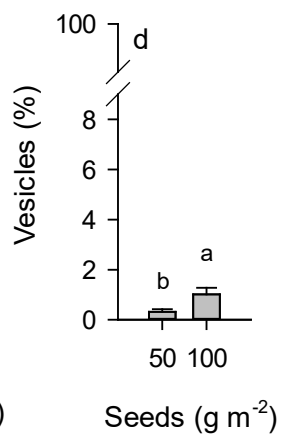

Figure 7. AMF colonization by fertilizer doses in the $2^{\text {nd }}$ summer (a), occurrence of arbuscules by inoculum doses in the $2^{\text {nd }}$ summer (b) and vesicles in the $3^{\text {rd }}$ summer by inoculum doses (c) and seed rates (d), at the inland site Árskógar (a) and the coastal site Mýrdalssandur (b-d). The columns represent treatment means and their SE. Different column letters show significant differences $(\mathrm{P}<0.05)$.

colonization at the moderate initial fertilizer level (Figure 8a) and among re-fertilized plants the lowest inoculum dose lowered AMF colonization compared to un-inoculated plants (Figure 8b).

A sporadic occurrence of arbuscules, $0 \%$ - $1.5 \%$ of root length, at the inland site was also dependent on variable interactions (Table 2). More arbuscules were found among uninoculated plants than those receiving the lowest inoculum dose at the moderate initial fertilizer dose, and more arbuscules were found among re-fertilized plants than without re-fertilization.

At the coastal site, the average AMF colonization was around $17.8 \%$ in the $2^{\text {nd }}$ summer but decreased in the $3^{\text {rd }}$ summer to $4.8 \%$. No variables significantly influenced AMF colonization, but arbuscule and vesicle numbers were influenced by input variables (Table 3). Arbuscule numbers in the $2^{\text {nd }}$ summer rose around elevenfold, to $5.7 \%$ of root length, at the lower inoculum level as compared to uninoculated plants (Figure 7b) and rose sixfold by doubling of initial fertilizer. Re-fertilization, however, negatively interacted with initial fertilizer (Table 3) and the highest arbuscule numbers, $7.4 \%$ of root length, were found in plants that were not re-fertilized and had received
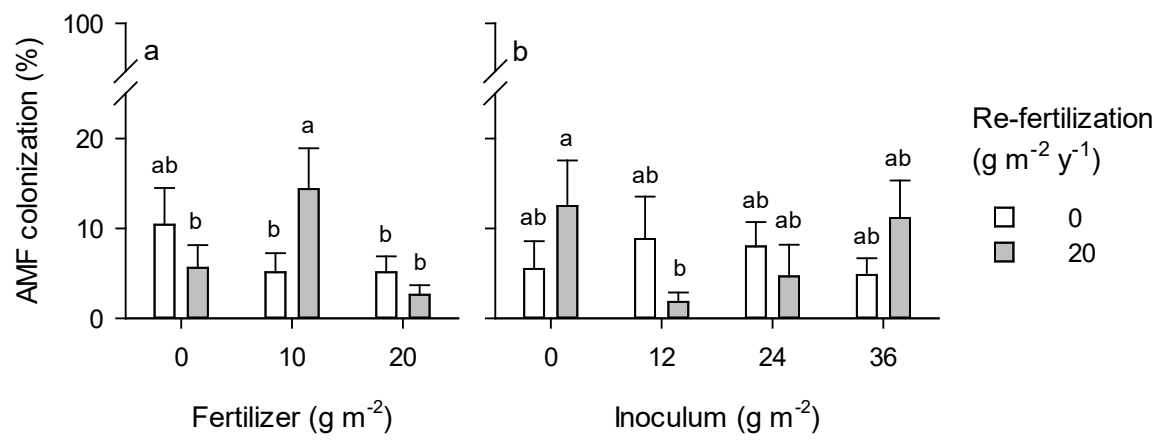

Figure 8. AMF colonization rates by fertilizer and re-fertilization (a) and by inoculum and re-fertilization (b) in the $2^{\text {nd }}$ summer at the inland site Arskógar. The columns represent treatment means and their SE. Different column letters show significant differences $(\mathrm{P}<0.05)$. 
a high initial fertilizer dose (not shown). Vesicle numbers in the $3^{\text {rd }}$ summer were influenced by inoculation and seed rates (Table 3). Inoculation increased by twenty times the occurrence of AM vesicles, regardless of inoculum dose (Figure $7 \mathrm{c}$ ), while doubling of seed numbers tripled AM vesicle formation (Figure 7d).

Dark septate endophytes were found in 1.8\% and $3.3 \%$ of root length at the inland and coastal sites, respectively, and were not influenced by treatment variables.

\section{Parameters of matured lyme grass}

In the $11^{\text {th }}$ summer, re-fertilization still had a predominant effect on lyme grass parameters, but treatments at the time of sowing were much less influential (Table $2 \& 3$ ). At both the inland and coastal sites, re-fertilization influenced all parameters (Table $2 \& 3$ ); re-fertilized plants at both sites were around 30\% higher than plants without re-fertilization (Figure 9a), the densities of re-fertilized plants at the inland and coastal sites were around 2.7 and 4.0 times higher, respectively (Figure 9b), and lyme grass plant cover at the inland and coastal sites was around 2.6 and 5.7 times higher, respectively (not shown). Furthermore, sand accretion in re-fertilized plots at the inland and coastal sites was around 8.0 and 70.1 times higher than without re-fertilization, respectively (Figure $9 \mathrm{c})$. At the inland site, destruction of study plots, where all seedlings were lost during winter floods, was also influenced by re-fertilization (Table 2); around 62\% more plots endured with than without re-fertilization (Figure 9d). Less associate vegetation grew in re-fertilized plots; its cover was $86 \%$ and $44 \%$ less at the inland and coastal sites, respectively, than in plots without re-fertilization (Figure 9e). Flower spike formation in the $11^{\text {th }}$ summer at the inland site was 5.0 times higher with re-fertilization (Figure 9f). The first flower spikes were detected in the $7^{\text {th }}$ summer after sowing but the variation in onset time of flowering could not be explained by treatment variables. No flowering was detected at the coastal site.

At the inland site in the $11^{\text {th }}$ summer, the positive effects of fertilization at the time of

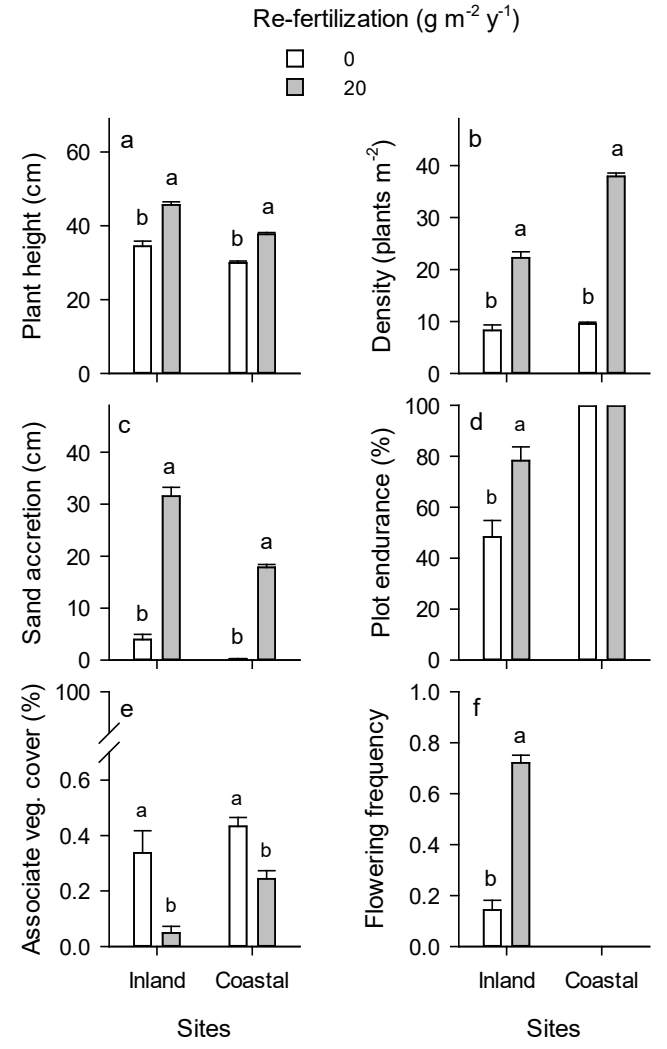

Figure 9. Variations in lyme grass plant height (a), lyme grass plant density (b), sand accretion (c), survival of experimental plots (d), associate vegetation cover (e) and lyme grass flowering frequency (f) by re-fertilization in the $11^{\text {th }}$ summer at both sites. The columns represent treatment means and their SE. Different column letters show significant differences between treatments $(\mathrm{P}<0.05)$.

sowing were still evident on lyme grass plant density and sand accretion (Table 2). These parameters were around three and ten times higher, respectively, at the highest fertilizer dose than without initial fertilizer (Figures 10a \& b). Initial fertilization was even more important than re-fertilization, preventing the loss of plots caused by poor seedling survival. Around three times more plots endured when fertilizer was initially applied (Figure 10c).

At the inland site, the interaction between re-fertilization and initial fertilization was also synergistic for plant density and sand accretion 

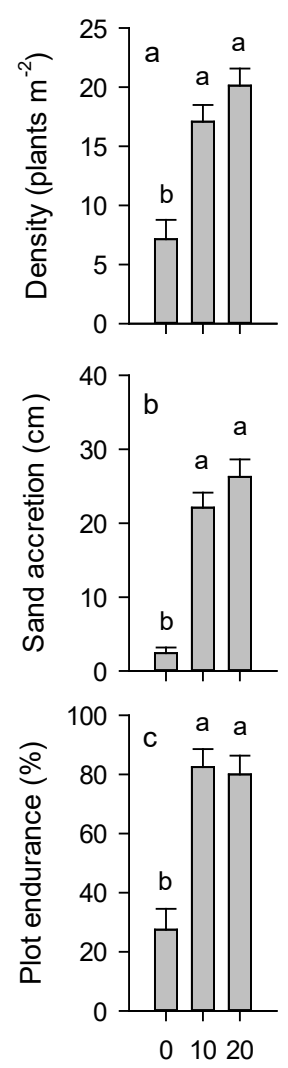

Fertilizer $\left(\mathrm{g} \mathrm{m}^{-2}\right)$

(Table 2). In plots without re-fertilization, sand accretion was only present in initially fertilized plots, regardless of amount, but in re-fertilized plots, initial fertilization dose had a greater influence on sand accretion, which reached 40 $\mathrm{cm}$ in plots receiving the greatest amount of total fertilizer (not shown). Plant density also showed a very similar pattern; it was lowest (1.8 plants $\mathrm{m}^{2}$ ) among plants not receiving any fertilizer but rose to 27.6 plants $\mathrm{m}^{-2}$ with the higher initial fertilizer dose combined with re-fertilization.

Associate vegetation cover was influenced by the interaction between initial fertilization and inoculation at the inland site (Table 2), where the highest cover, $0.6 \%$, was attained at a high inoculum level without initially applied fertilizer (not shown).

At the coastal site (Table 3), doubling of the initial fertilizer dose raised sand accretion

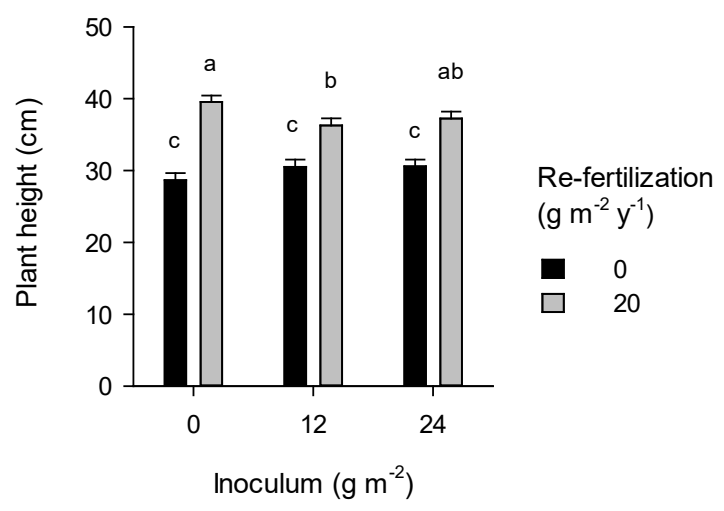

Figure 11. Variation in lymegrass vegetative regeneration in the $11^{\text {th }}$ summer by inoculum doses and re-fertilization at the coastal site Mýrdalssandur. The columns represent treatment means and their SE. Different column letters show significant differences $(\mathrm{P}<0.05)$.

by $20 \%$ (not shown). Initial fertilizer and re-fertilization showed a weak synergistic interaction for sand accretion, where most sand, $19 \mathrm{~cm}$ thick, accumulated on plots receiving the greatest amount of total fertilizer. Inoculation, however, reduced plant density by $10 \%$, as compared to un-inoculated plants, regardless of inoculum dose. Furthermore, doubling of seed rate increased plant density by $10 \%$, but reduced associate vegetation by $25 \%$.

While plant height at the coastal site (Table 3) was unaffected by inoculation in plots without re-fertilization, the height of re-fertilized plants receiving the moderate inoculum dose was $8 \%$ lower than un-inoculated plants (Figure 11). Associate vegetation grew best without refertilization in combination with a low seed rate (Table 3 ), but was reduced by a combination of re-fertilization and a high initial fertilizer dose.

Comparison of principal component evolution revealed strong temporal changes of treatment effects and variable responses in the experiment (Figure 12a \& b). While all lyme grass parameters showed a rather close affinity throughout the study period, the proximity was closest in the $11^{\text {th }}$ summer (Figure 12a \& 
b). Initial fertilization was closely allied to certain lyme grass parameters in the $1^{\text {st }}$ summer, particularly to lyme grass yield, plant size and vegetative regeneration at the inland site, but rapidly departed from these in the following years (Figure 12a \& b). Similarly, inoculation
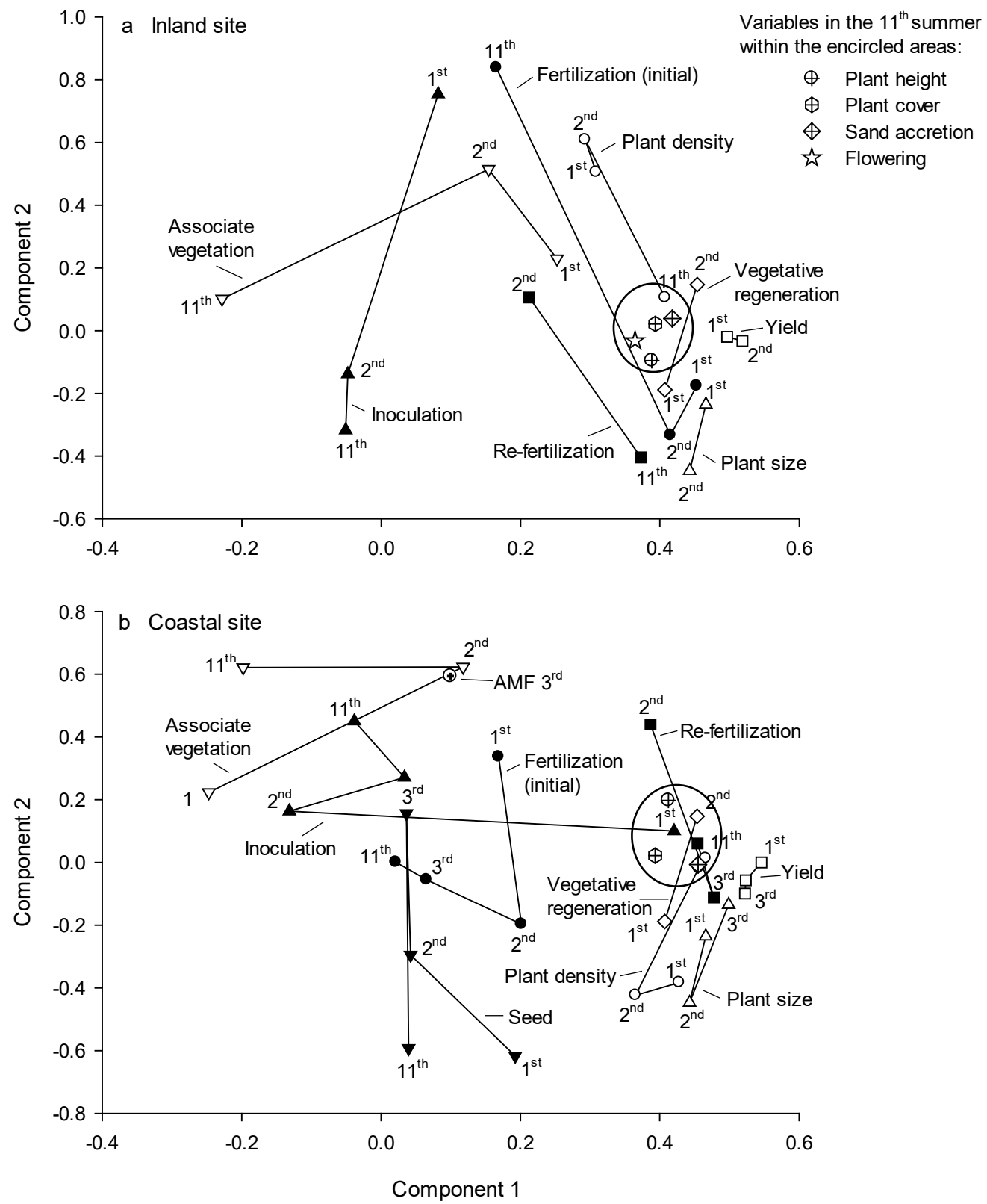

Figure 12. Temporal changes in the values of principal components 1 and 2 for given independent and response variables at the inland site Árskógar (a), and at the coastal site Mýrdalssandur (b). The numbers next to the legends indicate the summer since lyme grass sowing. The encircled areas contain all response variables in the $11^{\text {th }}$ summer, except for associate vegetation. 
started off in close proximity to lyme grass yield, plant size and vegetative regeneration at the coastal site but became distinct from lyme grass parameters in the $2^{\text {nd }}$ summer (Figure $12 \mathrm{~b})$. In the $11^{\text {th }}$ summer, the coordinates for refertilization were approximating those for lyme grass parameters, particularly at the coastal site, but other treatment variables remained dissimilar (Figure 12b). The coordinates for associate vegetation were different from other variables throughout the study time (Figure 12a $\&$ b). AMF colonization in the $3^{\text {rd }}$ summer at the coastal site was distinct from other lyme grass parameters, but simultaneously approximated the inoculation variable and associate vegetation coordinates (Figure 12b).

\section{DISCUSSION}

Inputs of resources for artificial seedling establishment strongly influence the outcomes of revegetation activities (Whisenant 1999). The most limiting factor for plant growth is usually the availability of soil nutrients, particularly $\mathrm{N}$ and P (Koide \& Dickie 2002). Hence nutrient inputs normally dominate seedling responses in nutrient deficient soils.

The present study showed that fertilizer inputs during lyme grass seedling establishment were crucial in achieving the primary aims of improving ecosystem services. First and foremost, $\mathrm{N}$ and $\mathrm{P}$ inputs are essential for lyme grass seedling survival as seen both in the present study and by Greipsson \& Davy (1997). Fertilizer inputs are also important to promote seedling growth to accomplish one of the main purposes of lyme grass employment, i.e. to trap drifting sand. One further measure of lyme grass management success is the onset of flowering and the flowering rate. Greipsson and Davy (1997) could induce flowering in the $4^{\text {th }}$ summer after sowing, three years earlier than it occurred at the inland site in the present study, by applying large annual $\mathrm{N}$ and $\mathrm{P}$ inputs $(10.4 \mathrm{~g} \mathrm{~N}$ and $5.6 \mathrm{~g} \mathrm{P}$ $\left.\mathrm{m}^{-2} \mathrm{y}^{-1}\right)$. This $\mathrm{N}$ fertilizer rate was more than twice that used in the present study, demonstrating the potential impact of fertilization. Greipsson and Davy (1997) also found that the rate of flowering and seed production was strongly dependent on $\mathrm{N}$ inputs. In the present study the onset and rate of flowering was not influenced by AMF inoculation treatments but was clearly controlled by fertilizer inputs at the inland site. It is not known why the lyme grass plants at the coastal site failed to flower during the study period. Presumably, more fertilizer inputs were needed to initiate flower formation because of greater nutrient losses through leaching from the higher rainfall at this site. A stronger positive growth response to re-fertilization also suggests a greater need for fertilization at the coastal site.

Fertilization and AMF inoculation initially benefitted growth of associate plant species in the present study. However, the rapid buildup of sand deposits caused a decline in all plants other than lyme grass. This was clearly indicated by the principal component analysis which showed that the dissimilarity between sand accretion and associate vegetation was greatest of all variables in the $11^{\text {th }}$ summer. Lyme grass seedlings can emerge from buried seeds from up to 15-20 $\mathrm{cm}$ depth and mature lyme grass tolerates even greater burial in sand (Greipsson \& Davy 1996).

Larger seed doses in the present study initially appeared to raise inter- and intraspecific competition, as indicated by a reduced rate of lyme grass vegetative reproduction and reduced growth of associate vegetation at high lyme grass seedling density. It is also likely that the higher AMF colonization observed at a high seed rate was a response to increased competition between lyme grass plants, as mycorrhizal plants are less affected by density than non-mycorrhizal plants of the same species (Hartnett et al. 1993).

Two of the associated plant species in the study, A. stolonifera and F. richardsonii, are AM plants (Greipsson \& El-Mayas 1999, Akhmetzhanova et al. 2012). These plant species were a potential source of mycorrhizal propagules in the experiment and may explain why lyme grass plants in un-inoculated plots were colonized by AMF. Although AMF propagules are normally infrequent at unvegetated sandy sites, propagules are spread 
from vegetated areas by wind, water and soil, and burrowing animals (Koske \& Gemma 1990, Fracchia et al. 2011) and gradually multiply under newly established vegetation patches (Greipsson et al. 2002, Koske \& Gemma 1997).

The present study employed the same isolate mixture as used by Enkhtuya et al. (2003) in which two of the isolates, G. hoi and $G$. claroideum, originated from lyme grass dunes in Iceland. Greipsson and El-Mayas (2000) also used native AMF from lyme grass dunes in Iceland in a pot study and found that these were better at enhancing lyme grass early growth than commercial AMF inoculum. Other studies have commonly indicated that the use of indigenous AMF isolates for inoculation may be more advantageous for plant growth than the use of exotic AMF isolates (e.g. Requena et al. 2001, Pellegrino et al. 2011).

Klironomos (2003) found that indigenous $\mathrm{AMF} /$ plant interactions were more variable than plant responses to exotic AMF. This means that the use of native AMF isolates provides a greater chance of finding more beneficial isolates among selection indigenous fungi than among exotic fungi. Plant/AMF interactions can also be dependent on ecotypic variation of both partners (Al Agely \& Sylvia 2008, Emery \& Rudgers 2011) which calls for a coordinated selection of AMF and plant material for ecosystem rehabilitation.

Lyme grass mutualistic responses to AMF inoculation in the $1^{\text {st }}$ summer may reflect improved nutrient uptake efficiency among young mycorrhizal seedlings. These benefits for early seedling growth are similar to those previously reported for lyme grass in a short term field study (Enkhtuya et al. 2003). However, commensal and parasitic responses of AMF inoculated plants, initiating in the second summer, show that the AMF treatments failed to provide continued plant benefits.

A parasitic plant growth response indicates that the cost of energy from photosynthates allocated to the root associations, which may be around $4-20 \%$ higher for mycorrhizal plants than for un-colonized plants (Smith \& Read 2008 and references therein), exceeds the benefits provided by the fungi (Johnson et al. 1997). Such responses are common in AMF inoculation trials (Hoeksema et al. 2010, Johnson et al. 1979 and references therein, Klironomos 2003). One of the probable reasons for this is that AM fungi can improve plant growth in $\mathrm{P}$ limited but not $\mathrm{N}$ limited systems, and $\mathrm{N}$ limitation can induce commensal or parasitic plant responses (Johnson et al. 2015). The underlying cause why lyme grass seedlings in sandy deserts are normally not colonized by AMF for the first few years (Greipsson et al. 2002) might therefore be an adaption to $\mathrm{N}$ limitation, where AMF cannot improve plant growth (Johnson et al. 2015).

Lyme grass has a particularly fibrous root system and long root hairs which may further signify the importance of a non-mycorrhizal mode for nutrient uptake (Baon et al. 1994, Bates \& Lynch 2001, Reinhardt \& Miller 1990, Schweiger et al. 1995). With time, lyme grass dunes slowly accumulate $\mathrm{N}$ from the surrounding area with an extensive root system (Leblans et al. 2014, Stefansdottir et al. 2014). The buildup of $\mathrm{N}$ within the dunes originating from atmospheric deposition averages $0.66 \mathrm{~g} \mathrm{~N} \mathrm{~m}^{-2} \mathrm{y}^{-1}$ (Stefansdottir et al. 2014) but within seagull colonies the rate of $\mathrm{N}$ buildup within lyme grass is much faster or $4.7 \mathrm{~g} \mathrm{~N} \mathrm{~m}^{-2} \mathrm{y}^{-1}$ (Leblans et al. 2014). Gradually, therefore, lyme grass probably changes from being predominantly $\mathrm{N}$ limited to being largely $\mathrm{P}$ limited. This change may coincide with the increase in AMF colonization of lyme grass roots during the onset of flowering, which occurs around 6-10 years after artificial lyme grass seedling establishment (Greipsson et al. 2002). This may also explain some of the intricate interactions between AMF inoculation and fertilizers observed in the present study, such as an occasional positive response in AMF colonization due to re-fertilization and possibly also, the initial synergistic interaction between AMF inoculation and fertilization. Increasing $\mathrm{N}$ fertilization, though, usually has negative effects on plant responses to AMF inoculation and generally reduces AMF colonization as well as occurrences of arbuscules and vesicles (Hoeksema et al. 2010), as seen in the present study. 
Based on the above information, further work on this topic should focus on improving and testing local AMF inocula in combination with moderate $\mathrm{N}$ and $\mathrm{P}$ amendments to create persisting conditions of $\mathrm{P}$ rather than $\mathrm{N}$ limitation. To achieve this, various types of slow release inorganic or organic fertilizers could be applied. The use of nitrogen fixing plants for this purpose could also be relevant.

In conclusion, the present results suggest that a more efficient use of resources for lyme grass seedling establishment could prove practical, involving low seed inputs $(\leq 50$ viable seeds $\mathrm{m}^{-2}$ ) in combination with low initial fertilization dose $\left(\leq 10 \mathrm{~g} \mathrm{~m}^{-2}\right)$. While repeated fertilization applications are clearly more effective than a large initial fertilizer dose, experiments are needed to fine tune seed and fertilizer inputs. Based on the current information, however, the application of AMF inoculation cannot be recommended for lyme grass establishment at un-vegetated sandy areas at present. Further knowledge on the responses of early successional plant species to management inputs and the role of microbial root associations under desert conditions is necessary for a continued progress of ecosystem rehabilitation methodology.

\section{ACKNOWLEDGEMENTS}

The present study was generously supported by the Soil Conservation Service, Iceland, and the Southern Region Institute for Advanced Learning. The contributions from Miroslav Vosátka of the Academy of Sciences, Czech Republic, Robert Patten at Plant Works Ltd. UK and numerous colleagues at the Soil Conservation Service, the Agricultural University of Iceland and University of Bremen are greatly appreciated.

\section{REFERENCES}

Akhmetzhanova AA, Soudzilovaskai NA, Onipchenko VG, Cornwell WK, Agafonov VA, Selivanov IA et al. 2012. A rediscovered treasure: Mycorrhizal intensity database for 3000 vascular plant species across the former Soviet Union. Ecology 93, 689.

Al Agely A \& Sylvia DM 2008. Compatible host/mycorrhizal fungus combinations for micropropagated sea oats: II. Field evaluation. Mycorrhiza 18, 257-261, doi: http://dx.doi.org/10.1007/s00572-008-0178-1.

Aradottir A 2007. Restoration of birch and willow woodland on eroded areas. In: Halldorsson G, Oddsdottir ES, Eggertsson O (eds.), Effects of afforestation on ecosystems, landscape and rural development. Proceedings of the AFFORNORD conference, Reykholt, Iceland, June 18-22, 2005. 508, pp 67-74. Copenhagen: TemaNord 2007, Nordic Council of Ministers.

Arnalds O 2010. Dust sources and deposition of aeolian materials in Iceland. Icelandic Agricultural Science 23, 3-21.

Arnalds $\mathbf{O}$ \& Kimble J 2001. Andisols of Deserts in Iceland. Soil Science Society of America Journal 65, 1778-1786.

Baon JB, Smith SE \& Altson AM 1994. Growth response and phosphorus uptake of rye with long and short root hairs. Plant and Soil 167, 247-254.

Bates TR \& Lynch JP 2001. Root hairs confer a competitive advantage under low phosphorus availability. Plant and Soil 236, 243-250.

Bever JD, Dickie IA, Facelli E, Facelli JM, Klironomos J, Moora M, Rilling MC, Stock WD, Tibbett M \& Zobel M 2010. Rooting theories of plant community ecology in microbial interactions. Trends in Ecology and Evolution 26, 468-478, doi: http://dx.doi.org/10.1016/j.tree.2010.05.004.

Busby RR, Gebhart DL, Stromberger ME, Meiman PJ \& Paschke MW 2011. Early seral plant species' interactions with and arbuscualar mycorrhizal fungi community are highly variable. Applied Soil Ecology 48, 257-262, doi:http://dx.doi.org/10.1016/j.apsoil.2011.04.014.

Cakan H \& Karatas C 2006. Interactions between mycorrhizal colonization and plant life forms along the successional gradient of 
coastal sand dunes in the eastern Mediterranean, Turkey. Ecological Research 21, 301-310, doi: http://dx.doi.org/10.1007/s11284-005-0134-x.

Cázares E, Trappe JM \& Jumpponen A 2005. Mycorrhiza-plant colonization patterns on a subalpine glacier forefront as a model system of primary succession. Mycorrhiza 15, 405-416, doi: http://dx.doi.org/10.1007/s00572-004-0342-1.

Corkidi L \& Rincón E 1997. Arbuscular mycorhizae in a tropical sand dune ecosystem on the Gulf of Mexico: II. Effects of arbuscular mycorrhizal fungi on the growth of species distributed in different early successional stages. Mycorrhiza 7, 17-23.

Enkhtuya B, Óskarsson Ú, Dodd J C \&Vosátka $M$ 2003. Inoculation of grass and tree seedlings used for reclaiming eroded areas in Iceland with mycorrhizal fungi. Folia Geobotanica 38, 209-222.

Emery SM \& Rudgers JA 2011. Beach Restoration Efforts Influenced by Plant Variety, Soil Inoculum, and Site Effects. Journal of Coastal Research 27, 636-644, doi: http://dx.doi.org/10.2112/jcoastres-d-10-00120.1.

Fracchia S, Krapovickas L, Aranda-Rickert A \& Valentinuzzi VS 2011. Dispersal of arbuscular mycorrhizal fungi and dark septate endophytes by Ctenomys cf. knighti (Rodentia) in the northern Monte Desert of Argentina. Journal of Arid Environments 75, 1016-1023, doi: http://dx.doi.org/10.1016/j.jaridenv.2011.04.034.

Greipsson S \& Davy AJ 1994. Leymus arenarius. Caracteristics and uses of a dune-building grass. Icelandic Agricultural Science 8, 41-50.

Greipsson S \& Davy AJ 1996. Sand accretion and salinity as constraints on the establishment of Leymus arenarius for land reclamation in Iceland. Annals of Botany 78, 611-618.

Greipsson S \& Davy AJ 1997. Responses of Leymus arenarius to nutrients: Improvement of seed prodution and seedling establisment for land reclamation. Journal of Applied Ecology 34, 11651176.

Greipsson S \& El-Mayas H 1999. Large-scale reclamation of barren lands in Iceland by aerial seeding. Land degradation \& development 10 , 185-193.

Greipsson S \& El-Mayas H 2000. Arbuscular mycorrhizae of Leymus arenarius on coastal sands and reclamation sites in Iceland and response to inoculation. Restoration Ecology 8, 144-150.

Greipsson S, El-Mayas H, Vestberg M \& Walker C 2002. Arbuscular mycorrhizal fungi in sandy soils in Iceland. Arctic, Antatctic, and Alpine Research 34, 419-427, doi: http://dx.doi.org/10.2307/1552199.

Gunnarsson TG \& Indridadottir GH 2009. Effect of sandplain revegetation on avian abundance and diversity at Skógasandur and Myrdalssandur, South-Iceland. Concervation Evidence 6, 98-104.

Harris J. 2009. Soil microbial communities and restoration ecology: Facilitators or followers? Science 325, 573-574, doi: http://dx.doi.org/10.1126/science.1172975.

Hartnett DC, Hetrick AD, Wilson GW \& Gibson DJ 1993. Mycorrhizal influence on intra- and interspecific neighbour interactions among cooccurring prairie grasses. Journal of Ecology 81, 787-795.

Herrera-Peraza RA, Hamel C, Fernández F, Ferrer RL \& Furrazola E 2011. Soil-strain compatibility: The key to effective use of arbuscular mycorrhizal inoculants. Mycorrhiza 21, 183-193, doi: http:// dx.doi.org/10.1007/s00572-010-0322-6.

Hodge A \& Storer K 2015. Arbuscular mycorrhiza and nitrogen: Implications for individual plants through to ecosystems. Plant and soil 386, 1-19, doi: http://dx.doi.org/10.1007/s11104-014-2162-1.

Hoeksema JD, Chaudhary VB, Gehring CA, Johnson NC, Karst J, Koide RT, et al. 2010. A meta-analysis of context-dependency in plant response to inoculation with mycorrhizal fungi. Ecology Letters 13, 394-407, doi: http:// dx.doi.org/10.1111/j.1461-0248.2009.01430.x.

Icelandic Meterological Office 2015. Retrieved 2015, from http://www.vedur.is

Johnson NC, Graham JH \& Smith FA 1997. Functioning of mycorrhizal associations along the mutualism-parasitism continuum. New Phytologist 138, 575-585.

Johnson NC, Wilson GWT, Wilson JA, Miller RM \& Bowker MA 2015. Mycorrhizal phenotypes and the Law of the Minimum. New Phytologist 205, 1473-1484, doi: http://dx.doi.org/10.1111/nph.13172.

Jung SC, Martinez-Medina A, Lopez-Raez JA, Pozo MJ 2012. Mycorrhiza-induced 
resistance and priming of plant defenses. Journal of Chemical Ecology 38, 651-664, doi: http://dx.doi.org/10.1007/s10886-012-0134-6.

Kernaghan G 2005. Mycorrhizal diversity: Cause and effect? Pedobiologia, 49, 511-520, doi: http:/dx.doi.org/10.1016/j.pedobi.2005.05.007.

Kikvidze Z, Armas C. Fukuda K, Martínez-García LB, Miyata M, Oda-Tanaka A, Pugnaire FI \& Wu B 2010. The role of arbuscular mycorrhizae in primary succession: Differences and similarities across habitats. Web Ecology 10, 50-57.

Klironomos JN 2003. Variation in plant responce to native and exotic arbuscular mycorrhizal fungi. Ecology 84, 2292-2301.

Koide RT \& Dickie IA 2002. Effects of mycorrhizal fungi on plant populations. Plant and Soil 244, 307-317.

Koske RE \& Gemma J N 1990. Va mycorrhizae in strand vegetation of Hawaii: Evidence for longdistance codispersal of plants and fungi. American Journal of Botany 77, 466-474.

Koske RE \& Gemma JN 1997. Mycorrhizae and succession in plantings of beachgrass in sand dunes. American Journal of Botany 84, 118-130.

Leake J, Johnson D, Donnelly D, Muckle G, Boddy L\& Read D 2004. Networks of power and influence: The role of mycorrhizal mycelium in controlling plant communities and agroecosystem functioning. Canadian Journal of Botany 82, 1016-1045, doi: http://dx.doi.org/10.1017/s0269915xo5003046.

Leblans NIW, Sigurdsson BD, Roefs P, Thuys R, Magnússon B \& Janssens IA 2014. Effect of seabird nitrogen input on biomass and carbon accumulation after 50 years of primary succession on a young volcanic island, Surtsey. Biogeosciences 11, 6237-6250, doi: http://dx.doi.org/10.5194/bg-11-6237-2014.

Maltz MR \& Treseder KK 2015. Sources of inocula influence mycorrhizal colonization of plants in restoration projects: a metaanalysis. Restoration ecology 23, 625-634, doi: http://dx.doi.org/10.1111/rec.12231.

McGonigle TP, Miller MH \& Evans DG 1990. A new method which gives an objective measure of colonization of roots by vesicular-arbuscular mycorrhizal fungi. New phytologist $115,495-501$.
Miller RM 2005. The nonmycorrhizal root - A stragegy for survival in nutrient-impoverished soils. Canadian Journal of Botany 165, 655-658.

OehI F, Schneider D, Sieverding E \& Burga CA2011. Succession of arbuscular mycorrhizal communities in the foreland of the retreating Morteratsch glacier in the Central Alps. Pedobiologia 54, 321-331, doi: http://dx.doi.org/10.1016/j.pedobi.2011.07.006.

Peel MC, Finlayson BL \& McMahon TA 2007. Updated world map of the Köppen-Geiger climate classification. Hydrology and Earth System Sciences 11, 1633-1644.

Pellegrino E, Bedini S, Avio L, Bonari E \& Giovannetti M 2011. Field inoculation effectiveness of native and exotic arbuscular mycorrhizal fungi in a Mediterranean agricultural soil. Soil Biology and Biochemistry 43, 367-376, doi: http://dx.doi.org/10.1016/j.soilbio.2010.11.002.

Reinhardt DR \& Miller RM 1990. Size-classes of root diameter and mycorrhizal fungus colonization in two temperate grassland communities. New Phytologist 116, 129-136.

Requena N, Perez-Solis E, Azcón-Aguilar C, Jeffries P \& Barea J-M 2001. Management of indigenous plant-microbe symbioses aids restoration of desertified ecosystems. Applied and Environmental Microbiology 67, 495-498.

SAS Institute Inc. 2002-2008. SAS 9.2 for Windows. Cary, NC, USA: SAS Institute Inc.

Schweiger PF, Robson AD \& Barrow NJ 1995. Root hair length determines beneficial effect of a Glomus species on shoot growth of some pasture species. New Phytologist 131, 247-254.

Simard SW \& Durall DM 2004. Mycorrhizal networks: A review of their extent, function, and importance. Canadian Journal of Botany 82, 11401165, doi: http://dx.doi.org/10.1139/B04-116.

Smith S E, Read D J 2008. Mycorrhizal Symbiosis, 3rd ed. New York: Acadamic Press. 787 p.

Stefansdottir G, Aradottir AL \& Sigurdsson BD 2014. Accumulation of nitrogen and organic matter during primary succession of Leymus arenarius dunes on the volcanic island Surtsey, Iceland. Biogeosciences 11, 5763-5771, doi: http://dx.doi.org/10.5194/bg-11-5763-2014. 
Thordarson T \& Larsen G 2007. Volcanism in Iceland in historical time: Volcano types, eruption styles and eruptive history. Journal of Geodynamics 43, 118-152, doi: http://dx.doi.org/10.1016/j.jog.2006.09.005.

van der Heijden MGA\& Horton TR 2009. Socialism in soil? The importance of mycorrhizal fungal networks for facilitation in natural ecosystems. Journal of Ecology 97, 1139-1150, doi: http:// dx.doi.org/10.1111/j.1365-2745.2009.01570.x.

van der Heijden MGA, Martin FM, Selosse M-A \& IR Sanders 2015. Mycorrhizal ecology and evolution: The past, the present, and the future. New Phytologist 205, 1406-1423, doi: http://dx.doi.org/10.1111/nph.13288.

Vierheilig H, Coughlan AP, Wyss U \& Piché Y 1998. Ink and vinegar, a simple staining technique for arburcular-mycorrhizal fungi. Applied and environmental microbiology 64, 5004-5007.

Whisenant S 1999. Repairing Damaged Wildlands: A Process-Orientated, Landscape-Scale Approach: Volume 1: Biological Conservation, Restoration, and Sustainability. Cambridge, UK: Cambridge University Press. 312 p.

Yamauchi A, Nishida T \& Ohgushi T 2009. Stochastic tunneling in the colonization of mutualistic organisms: primary succession by mycorrhizal plants. Journal of Theoretical Biology 261, 74-82, doi: http://dx.doi.org/10.1016/j.jtbi.2009.07.021.

Manuscript received 11 March 2015 Accepted 27.10.2015 